\title{
THIRTY-FOURTH ANNUAL LIST OF PAPERS
}

\author{
READ BEFORE THE AMERICAN MATHEMATICAL SOCIETY AND \\ SUBSEQUENTLY PUBLISHED, INCLUDING REFERENCES \\ TO THE PLACES OF PUBLICATION
}

Alexander, J. W. Topological invariants of manifolds. Read 0ct. 25, 1924. Proceedings of the National Academy of Sciences, vol. 10, No. 12, pp. 493-494; Dec., 1924.

BARNETT, I. A. On a class of transformations in function space. Read April 14, 1923. Annals of Mathematics, (2), vol. 25, No.3, pp. 205-220; March, 1924.

Integro-differential equations. Read Dec. 29, 1923. This Bulletin, vol. 31, Nos. 5-6, pp. 263-265; May-June, 1925.

BELL, E. T. Certain products involving the divisors of numbers. Read (San Francisco Section) April 5, 1924. Bulletin of the Calcutta Mathematical Society, vol. 15, No. 1, pp. 21-24; June, 1924. Theta functions and arithmetic. Read (San Francisco Section) April 7, 1923. Annals of Mathematics, (2), vol. 26, Nos. 1-2, pp. 79-87; Sept.-Dec., 1924.

Representations of integers in certain binary, ternary, quaternary and quinary quadratic forms and allied class number relations. Read Dec. 27, 1923. Annals of Mathematics, (2), vol. 26, Nos. 1-2, pp. 155-164; Sept.-Dec., 1924.

Notes on recurring series of the third order. Read (San Francisco Section) Sept. 18, 1923. Tôhoku Mathematical Journal, vol. 24, Nos. 1-2, pp. 168-184; Dec., 1924.

On the number of representations of an integer as a sum or difference of two cubes. Read (San Francisco Section) June 19, 1925. This Bulletin, vol. 31, No. 7, pp. 309-312; July, 1925.

Bennet, A. A. Five axioms for point and translation in affine geometry. Read Dec. 30, 1924. This Bulletin, vol. 30, Nos. 9-10, pp.520-526; Nov.-Dec., 1924.

- On sets of three consecutive integers which are quadratic residues of primes. Read April 10, 1925. This Bulletin, vol. 31, No. 8, pp. 411-412; 0ct., 1925.

BuIss, G. A. Algebraic functions and their divisors. Read April 19, 1924. Annals of Mathematics, (2), vol. 26, Nos. 1-2, pp. 95-124; Sept.-Dec., 1924.

Brinkmane, H. W. Einstein spaces which are mapped conformally on each other. Read April 28, 1923. Mathematische Annalen, vol. 94, Nos. 1-2, pp. 119-145; April, 1925.

BRown, B. H. Contact transformations linear in $x, y, z$; applications to equilong transformations. Read Dec. 27, 1922. Annals of Mathematics, (2), vol. 26, Nos. 1-2, pp. 1-7; Sept.-Dec., 1924.

CAJorI, F. Empirical generalizations on the growth of mathematical notations. Read (San Francisco Section) Sept. 18, 1923. Isis, vol. 6 , No. 3, pp. 391-394; 1924.

Note on our sign of equality. Read (San Francisco Section) April 5, 1924. Isis, vol. 6, No. 4, pp. 507-508; 1924. 
Cajori, F. Notes on Luca Pacioli's "Summa." Read (San Francisco Section) April 5, 1924. Archivio di Storia della Scienza, vol. 5, No. 2, pp. 125-130; June, 1924.

Despiau's Select Amusements. Read (San Francisco Section) April5, 1924. Mathematical Gazette, vol. 12, No. 172, p. 216; Oct., 1924. Fanciful hypotheses on the origin of the numeral forms. Read (San Francisco Section) Oct. 25, 1924. Mathematics Teacher, vol. 18, No. 3, pp. 129-133; March, 1925.

Early printed forms of our dollar mark. Read (San Francisco Section) April 4, 1925. School and Society, vol. 21, No. 543, pp. 625-626; May 23, 1925.

CAMP, B. H. Probability integrals for a hypergeometric series. Read Oct. 25, 1924. Biometrica, vol. 17, Nos. 1-2, pp. 61-67; June, 1925.

CARIs, P. A. A solution of the quadratic congruence modulo $p$ $p=8 n+1, n$ odd. Read April 10,1925. American Mathematical Monthly, vol. 32, No. 6, pp. 294-299; June-July, 1925.

Carpenter, A. F. Projective properties of a ruled surface in the neighborhood of a ruling. Read (San Francisco Section) Sept. 18, 1923, and (San Francisco Section) Dec. 22, 1923. American Journal of Mathematics, vol. 46, No. 4, pp. 241-257; Oct., 1924.

- Cone-cubic configurations of a ruled surface. Read (San Francisco Section) April 5, 1924. Transactions of this Society, vol. 27, No. 4, pp. 397-415; Oct., 1925.

Castellani, M. Algebraic surfaces with reducible bitangent and osculating hyperplanar sections. Read May 2, 1925. Transactions of this Society, vol. 27, No. 3, pp. 279-286; July, 1925.

Church, A. On irredundant sets of postulates. Read Dec. 30, 1924. Transactions of this Society, vol. 27, No. 3, pp. 318-328; July, 1925.

Cummings, L. D. A new type of double sextette closed under a binary $(3,3)$ correspondence. Read Oct. 25, 1924. This Bulletin, vol. 31, Nos. 5-6, pp. 266-274; May-June, 1925.

Davis, H. T. An extension of the problem of the elastic bar. Read Dec. 29, 1922, and Dec. 26, 1924. American Journal of Mathematics, vol. 47, No. 2, pp. 101-120; April, 1925.

Dickson, L. E. Differential equations from the group standpoint. Read April 15, 1922. Annals of Mathematics, (2), vol. 25, No. 4, pp. 287-378; June, 1924.

DoDd, E. L. The frequency law of a function of one variable. Read Dec. 30 , 1924. This Bulletin, vol. 31, Nos. 1-2, pp. 27-31; Jan.-Feb., 1925.

Douglas, J. A criterion for the conformal equivalence of a Riemann space to a euclidean space. Read 0ct. 27, 1923. Transactions of this Society, vol. 27, No. 3, pp. 299-306; July, 1925.

Edington, W. E. On an infinite system of non-abelian groups of order $\mathrm{nm}^{n}$. Read Dec. 29, 1922. Annals of Mathematics, (2), vol. 26, No. 3, pp. 233-238; March, 1925.

EiesLand, J. The group of motions of an Einstein space. Read March 26, 1921, Sept. 8, 1921, and Sept. 7, 1923. Transactions of this Society, vol. 27, No. 2, pp. 213-245; April, 1925.

Eisenhart, L. P. Fields of parallel vectors in a Riemannian geometry. Read Feb. 28, 1925. Transactions of this Society, vol. 27, No. 4, pp. 563-573; 0ct., 1925. 
EmcH, A. On plane algebraic curves which remain invariant under a quadratic Cremona transformation, their classification, and relation to the Cayley cubic surface. Read Dec. 28, 1921. Tôhoku Mathematical Journal, vol. 24, Nos. 1-2, pp. 68-87; Dec., 1924.

Determination of plane alg'ebraic curves which are invariant under involutory Cremona transformations. Read April 10, 1925. Tôhoku Mathematical Journal, vol. 25, Nos. 1-2, pp. 63-76; May, 1925.

- On the Weddle surface and analogous loci. Read Dec. 29, 1923. Transactions of this Society, vol. 27, No. 3, pp. 270-278; July, 1925.

ForD, L. R. On the closeness of approach of complex rational fractions to a complex irrational number. Read April 24, 1920. Transactions of this Society, vol. 27, No. 2, pp. 146-154; April, 1925. The fundamental region of a Fuchsian group. Read Sept. 11; 1925. This Bulletin, vol. 31, Nos. 9-10, pp. 531-539; Nov.-Dec., 1925.

Franklin, P. Analytic transformations of everywhere dense point sets, Read May 3, 1924. Transactions of this Society, vol. 27, No. 1. pp. 91-100; Jan., 1925.

The rotating disc. Read Oct. 25, 1924. Proceedings of the National Academy of Sciences, vol. 11, No. 2, pp. 147-149; Feb., 1925.

- Functions with an essential singularity. Read May 3, 1924. This Bulletin, vol. 31, Nos. 3-4, pp. 157-162; March-April, 1925. The electric currents in a network. Read Oct. 25, 1924. Journal of Mathematics and Physics of the Massachusetts Institute of Technology, vol. 4, No. 2, pp. 97-102; April, 1925.

- The Weierstrass approximation theorem. Read Dec. 30, 1924. Journal of Mathematics and Physics of the Massachusetts Institute of Technology, vol. 4, No. 3, pp. 148-152; May, 1925.

Garabedian, C. A. Quatre méthodes pour résoudre le problème de la poutre rectangulaire. Read Oct. 25, 1924. Comptes Rendus de l'Académie des Sciences, vol. 179, No. 7, pp. 381-384; Aug. 18, 1924. Rods of constant or variable cross section. Read April 28, 1923. American Journal of Mathematics, vol. 46, No. 4, pp. 273-287; Oct., 1924.

- Solution du problème de la plaque rectangulaire épaisse encastrée ou posée, portant une charge uniformément répartie ou concentrée en son centre. Read Feb. 28, 1925. Comptes Rendus de l'Académie des Sciences, vol. 180, No. 4, pp. 257-259; Jan. 26, 1925.

GLENN, O.E. A note on the abundance of differential combinants in a fundamental system. Read May 3, 1924. Proceedings of the National Academy of Sciences, vol.11, No.6, pp.281-284; June, 1925.

Graustern, W. C. Real representations of analytic complex curves. Read Sept. 7, 1922. Annals of Mathematics, (2), vol. 26, Nos. 1-2. pp. 131-143; Sept.-Dec., 1924.

Griffiths, L. W. Contact curves of the rational plane cubic. Read (San Francisco Section) Dec. 22, 1923. This Bulletin, vol. 31, No. 7, pp. 312-317; July, 1925.

Gronwall, T. H. The mutual inductance of two square coils. Read April 28, 1923. Transactions of this Society, vol. 27, No. 4, pp. 516-536; Oct., 1925.

Hancock, H. The foundations of the theory of algebraic numbers. Read Dec. 31, 1924. Science, new ser., vol. 61, No. 1566, pp.5-10, and No. 1567, pp. 30-35; Jan. 2 and Jan. 9, 1925. 
Hedrick, E. R., and INGoLd, L. Analytic functions in three dimensions. Read Sept. 7, 1923. Transactions of this Society, vol. 27, No. 4, pp. 551-555; 0ct., 1925.

The Beltrami equations in three dimensions. Read (Southwestern Section) Dec. 1, 1923. Transactions of this Society, vol. 27, No.4, pp. 556-562; 0ct., 1925.

Henderson, A. Is the universe finite? Read Jan. 1, 1925. American Mathematical Monthly, vol. 32, No. 5, pp. 213-223; May, 1925.

Henderson, R. Life insurance as a social service and as a mathematical problem. Read Dec. 30, 1924. This Bulletin, vol. 31, Nos. 5-6, pp. 227-252; May-June, 1925.

HILLE, E. Note on Dirichlet's series with complex exponents. Read April 28, 1923. Annals of Mathematics, (2), vol. 25, No. 3, pp. 261-278; March, 1924.

-_ A general type of singular points. Read 0ct. 25, 1924. Proceedings of the National Academy of Sciences, vol. 10, No. 12, pp. 488-493; Dec., 1924.

On the zeros of the functions of the parabolic cylinder. Read Dec. 27, 1923. Arkiv for Matematik, Astronomi och Fysik, vol. 18, No. 26, pp. 1-56; Jan., 1925.

A note on regular singular points. Read Oct. 25, 1924. Arkiv for Matematik, Astronomi och Fysik, vol. 19 A, No. 2, pp. 1-21; April, 1925.

Hollcroft, T. R. Maximal cuspidal curves. Read Feb. 25, 1922. Annals of Mathematics, (2), vol. 26, Nos. 1-2, pp. 37-46; Sept.Dec., 1924.

- Limits for actual double points of space curves. Read Feb. 24, 1923. This Bulletin, vol. 31, Nos. 1-2, pp. 42-55; Jan.-Feb., 1925.

Hopkins, L. A. On periodic orbits for the characteristic planets. Read Sept. 7, 1920. Astronomical Journal, vol. 36, Nos. 4-5, pp. 25-33; Nov. 11, 1924.

Hotelling, H. Three-dimensional manifolds of states of motion. Read (San Francisco Section) 0ct. 25, 1924. Transactions of this Society, vol. 27, No. 3, pp. 329-344; July, 1925.

HUBER, C. M. On the prime divisors of the cyclotomic functions. Read 0ct. 25, 1924. Transactions of this Society, vol.27, No. 1, pp.43-48; Jan., 1925.

Hurwitz, W. A. Characteristic parameter values for an integral equation. Read Dec. 30, 1924. This Bulletin, vol. 31, Nos. 9-10, pp. 503-508; Nov.-Dec., 1925.

Hutchinson, J. I. On the roots of the Riemann zeta function. Read Oct. 25, 1924. Transactions of this Society, vol. 27, No. 1, pp. 49-60; Jan., 1925.

INGOLD, L. Associated types of linear connection. Read April 11, 1925. Proceedings of the National Academy of Sciences, vol. 11, No.5, pp. 252-256; May, 1925.

A symbolic treatment of the geometry of hyperspace. Read (Southwestern Section) Dec. 1, 1923. Transactions of this Society, vol. 27, No. 4, pp. 574-599; Oct., 1925.

See HeDrick, E. R. 
Ingraham, M. H. A general theory of linear sets. Read April 11, 1925. Transactions of this Society, vol. 27, No. 2, pp. 163-196; April, 1925.

JAckson, D. On the method of least $m$ th powers for a set of simultaneous equations. Read Dec. 30, 1920. Annals of Mathematics, (2), vol. 25, No. 3, pp. 185-192; March, 1924.

- A general class of problems in approximation. Read Dec. 29, 1922. American Journal of Mathematics, vol. 46, No. 4, pp. 215-234; Oct., 1924.

On the trigonometric representation of an ill-defined function. Read Dec. 30, 1920. Annals of Mathematics, (2), vol. 26, Nos. 1-2, pp. 8-20; Sept.-Dec., 1924.

The elementary geometry of function space. Read April 19, 1924. American Mathematical Monthly, vol. 31, No. 10, pp. 461-471; Dec., 1924.

The geometry of frequency functions. Read Oct. 25, 1924. This Bulletin, vol. 31, Nos. 1-2, pp. 63-73; Jan.-Feb., 1925.

JAMEs, G. An algebraically reducible solution of the cubic equation, Read Feb. 28, 1925. American Mathematical Monthly, vol. 32. No. 4, pp. 162-169; April, 1925.

KASNER, E. An algebraic solution of the Einstein equations. Read Oct. 29, 1921. Transactions of this Society, vol. 27, No. 1, pp. 101-105; Jan., 1925.

__ Separable quadratic differential forms and Einstein solutions. Read May 3, 1924. Proceedings of the National Academy of Sciences, vol. 11, No. 1, pp. 95-96; Jan., 1925.

- Solutions of the Einstein equations involving functions of only one variable. Read Sept. 7, 1921. Transactions of this Society, vol. 27, No. 2 , pp. 155-162; April, 1925.

Kempner, A.J. Polynomials of several variables and their residue systems. Read Dec. 26, 1924. Transactions of this Society, vol. 27, No. 3, pp. 287-298; July, 1925.

Keyser, C. J. Concerning groups of dyadic relations of an arbitrary field. Read April 26, 1919. Fundamenta Malhematicae, vol. 7, pp. 323-339; 1925.

KIINE, J. R. Concerning the complementary intervals of countable closed sets. Read Oct. 25, 1924. This Bulletin, vol. 31, No. 8, pp. 409-410; Oct., 1925. Concerning the sum of two continua each irreducible between the same pair of points. Read May 3, 1924. Fundamenta Mathematicae, vol. 7, pp. 314-322; 192 อ̃.

LEHMER, D. N. A new method of factorization. Read (San Francisco Section) April 4, 1925. Proceedings of the National Academy of Sciences, vol. 11, No. 1, pp. 97-98; Jan., 1925.

Note on the construction of tables of linear forms. Read (San Francisco Section) June 19, 1925. This Bulletin, vol.31, Nos. 9-10, pp. 497-498; Nov.-Dec., 1925.

LEvy, H. Normal congruences of curves in Riemann space. Read April 28, 1923. This Bulletin, vol. 31, Nos. 1-2, pp. 39-42; Jan.Feb., 1920 .

Ricci's coefficients of rotation. Read May 3, 1924. This Bulletin, vol. 31, Nos. 3-4, pp. 142-145; March-April, 1425. 
Lrbman, E. E. The linear complex of conics. Read Feb. 28, 1925. Transactions of this Society, vol. 27, No. 3, pp. 265-269; July, 1925.

LogsDon, M. I. Complete groups of points on a plane cubic curve. Read Dec. 29; 1922. Transactions of this Society, vol. 27, No.4, pp. 474-490; Oct., 1925.

MacDuffee, C. C. On the complete independence of the functional equations of involution. Read April 28, 1923. This Bulletin, vol. 31, Nos. 1-2, pp. 21-26; Jan.-Feb., 1925.

MacMillan, W. D. Some mathematical aspects of cosmology. Read April 10, 1925. Science, new ser., vol. 62, No. 1595, pp. 63-72, No. 1596, pp. 96-99, and No. 1597, pp. 121-127; July 24, July 31, and Aug. 7, 1925.

MARCH, H. W. Deflection of a rectangular plate fixed at the edges. Read Dec. 29, 1923. Transactions of this Society, vol. 27, No.3, pp. 307-317; July, 1925.

Merriman, G. M. On certain theorems regarding summable series and their application to the double and triple Fourier's series. Read Dec. 28, 1923, and Dec. 29, 1924. American Journal of Mathematics, vol. 47, No. 2, pp. 125-139; April, 1925.

Mrchal, A. D. Functionals of curves admitting one-parameter groups of infinitesimal point transformations. Read Dec. 28, 1923. Proceedings of the National Academy of Sciences, vol.11, No. 1, pp. 98-101; Jan., 1925.

Integro-differential expressions invariant under Volterra's group of transformations. Read April 28, 1923. Annals of Mathematics, (2), vol. 26, No. 3, pp. 181-201; March, 1925.

- Functional invariants, with a continuity of order $p$, of one-parameter Fredholm and Volterra transformation groups. Read Oct. 25, 1924. This Bulletin, vol. 31, No. 7, pp. 335-346; July, 1925.

Mrlier, G. A. The subgroup composed of the substitutions which omit a letter of a transitive group. Read Dec. 26, 1924. Transactions of this Society, vol. 27, No. 2, pp. 137-145; April, 1925.

Moore, C. L. E. Minimal varieties of two or three dimensions whose element of arc is a perfect square. Read Feb. 28, 1925. Journal of Mathematics and Physics of the Massachusetts Institute of Technology, vol. 4, No. 3, pp. 167-178; May, 1925.

Moore, C. N. On the application of Borel's method to the summation of Fourier's series. Read Dec. 29, 1924. Proceedings of the National Academy of Sciences, vol.11, No.6, pp.284-287; June, 1925.

Moore, R. L. Concerning upper semi-continuous collections of continua which do not separate a given continuum. Read (Southwestern Section) Nov. 29, 1924. Proceedings of the National Academy of Sciences, vol. 10, No. 8, pp. 356-360; Aug., 1924.

Concerning sets of segments which cover a point set in the Vitali sense. Read (Southwestern Section) Nov. 29, 1924. Proceedings of the National Academy of Sciences, vol. 10, No. 11, pp.464-467; Nov., 1924.

Concerning the prime parts of a continuum. Read Sept. 7, 1923. Mathematische Zeitschrift, vol. 22, Nos. 3-4, pp.307-315; Feb., 1925. A characterization of a continuous curve. Read May 3, 1924. Fundamenta Mathematicae, vol. 7, pp. 302-307; 1925. 
Moore, R. L. Concerning the separation of point sets by curves. Read Sept. 10, 1925. Proceedings of the National Academy of Sciences, vol. 11, No. 8, pp. 469-476; Aug., 1925.

Concerning upper semi-continuous collections of continua. Read Dec. 30, 1924. Transactions of this Society, vol. 27, No. 4, pp. 416-428; Oct., 1925.

MorItz, R.E. On the kinematic construction of certain higher plane curves. Read (San Francisco Section) April 4, 1925. American Mathematical Monthly, vol. 32, No. 6, pp. 302-305; June-July, 1925.

Monse, M. Relations between the critical points of a real function of $n$ independent variables. Read Dec. 28, 1923. Transactions of this Society, vol. 27, No. 3, pp. 345-396; July, 1925.

Murnaghan, F. D. The tensor character of the generalized Kronecker symbol. Read March 1, 1924. This Bulletin, vol. 31, No. 7, pp. 323-329; July, 1925.

MurRay, F.H. Generalization of certain theorems of Bohl. Read March 1, 1924. American Journal of Mathematics, vol. 47, No. 1, pp. 25-44; Jan., 1925.

OLson, H. L. Congruences with constant absolute invariants. Read Feb. 28, 1925. Transactions of this Society, vol. 27, No. 1, pp. 15-42; Jan., 1925.

OsGood, W. F. On normal forms of differential equations. Read Feb. 28, 1925. Transactions of this Society, vol. 27, No.1, pp. 1-14; Jan., 1925.

Pupin, M. I. From chaos to cosmos. Read Feb. 29, 1924. Scribner's Magazine, vol. 76, No. 1, pp. 3-10; July, 1924.

RAINICH, G. Y. Electrodynamies in the general relativity theory. Read Feb. 24, 1923, Dec. 27, 1923, March 1, 1924, May 3, 1924, and Oct. 25, 1924. Transactions of this Society, vol. 27, No. 1, pp. 106-136; Jan., 1925.

- Second paper on tensor analysis. Read March 1, 1924. American Journal of Mathematics, vol. 47, No. 1, pp. 11-24; Jan., 1925.

_ Sur une représentation des surfaces. Read Dec. 29, 1924. Comptes Rendus de l'Académie des Sciences, vol. 180, No. 11, pp. 801-803; March 16, 1925.

REILLY, J. F. Certain generalizations of osculatory interpolation, Read April 14, 1922. The Record, American Institute of Actuaries. vol. 13, No. 1, pp. 4-22; June, 1924.

On Lidstone's demonstration of the osculatory interpolation formula. Read (Southwestern Section) Nov. 29, 1924. The Record, American Institute of Actuaries, vol. 14, No. 1, pp. 12-20; June, 1925.

ReINsch, B. P. Expansion problems in connection with the hypergeometric differential equation. Read April 19, 1924. American Journal of Mathematics, vol. 47, No. 1, pp. 45-70; Jan., 1925.

RIETZ, H. L. On the representation of a certain fundamental law of probability. Read April 13, 1923. Transactions of this Society, vol. 27, No. 2, pp. 197-212; April, 1925.

RitT, J. F. Note on Dirichlet's series with complex exponents. Read Dec. 28, 1923. Annals of Mathematics, (2), vol. 26, Nos. 1-2, p. 144; Sept.-Dec., 1924. 
Ritr, J.F. Elementary functions and their inverses. Read Oct. 25, 1924. Transactions of this Society, vol. 27, No.1, pp. 68-90; Jan., 1925.

New proofs of two well known theorems on quadratic forms. Read March 1, 1924. Annals of Mathematics, (2), vol. 26, No. 3, pp. 202-204; March, 1925.

RoE, E. D. Integral functions as products. Read Sept. 5, 1917. Publications of the Roe Observatory, No. 1, pp. 1-6; Jan., 1924.

Roever, W. H. Some phases of descriptive geometry. Read (Southwestern Section) Nov. 29, 1924. This Bulletin, vol. 31, Nos. 9-10, pp. 540-550; Nov.-Dec., 1925.

Romig, H. G. Early history of division by zero. Read (San Francisco Section) Sept. 18, 1923. American Mathematical Monthly, vol. 31, No. 8, pp. 387-389; Oct., 1924.

Schouten, J. A. On the conditions of integrability of covariant differential equations. Read Sept. 10, 1925. Transactions of this Society, vol. 27, No. 4, pp. 441-473; 0ct., 1925.

Sнонат, J. A. On the development of a continuous function into a series of Tchebycheff polynomials. Read April 19, 1924. Transactions of this Society, vol. 27, No. 4, pp. 537-550; Oct., 1925.

- On the polynomial of the best approximation to a given continuous function. Read Dec. 26, 1924. This Bulletin, vol. 31, Nos. 9-10; pp. 509-514; Nov.-Dec., 1925.

SmaIL, L. L. History and synopsis of the theory of summable infinite processes. Read (San Francisco Section) June 18, 1920, and (San Francisco Section) April 7, 1923. University of Oregon Publication, vol. 2, No. 8, 6+175 pp.; Feb., 1925.

Smith, H. L. On the existence of the Stieltjes integral. Read Dec. 29, 1923. Transactions of this Society, vol. 27, No. 4, pp. 491-515; Oct., 1925.

SNyder, V. On the types of monoidal involutions. Read Dec. 27, 1923. Annals of Mathematics, (2), vol.25, No.3, pp. 279-284; March, 1924.

- Non-monoidal involutions which contain a web of invariant monoids. Read April 18, 1924. Annals of Mathematics, (2), vol. 26, No. 3, pp. 165-172; March, 1925.

Stone, M. H. On the order of an analytic function at a singular point. Read March 1, 1924. Annals of Mathematics, (2), vol. 26, Nos. 1-2, pp. 145-154; Sept.-Dec., 1924.

Synge, J. L. A generalization of the Riemannian line-element. Read Dec. 30, 1924. Transactions of this Society, vol. 27, No. 1, pp. 61-67; Jan., 1925.

TAyLoR, J. H. A generalization of Levi-Civita's parallelism and the Frenet formulas. Read April 19, 1924. Transactions of this Society, vol. 27, No. 2, pp. 246-264; April, 1925.

Reduction of Euler's equations to a canonical form. Read 0ct. 25, 1924. This Bulletin, vol.31, Nos. 5-6, pp. 257-262; May-June, 1925.

Thомas, J. M. Congruences of circles studied with reference to the surface of centers. Read Sept. 7, 1923. Annals of Mathematics, (2), vol. 25, No. 3, pp. 221-237; March, 1924.

Note on the projective geometry of paths. Read Feb. 28, 1925. Proceedings of the National Academy of Sciences, vol. 11, No. 4, pp. 207-209; April, 1925. 
Thomas, J. M. Conformal correspondence of Riemann spaces. Read May 2, 1925. Proceedings of the National Academy of Sciences, vol. 11, No. 5, pp. 257-259; May, 1925.

The number of even and odd absolute permutations of $n$ letters. Read Feb. 28, 1925. This Bulletin, vol. 31, No. 7, pp. 303-304; July, 1925 .

See Veblen, 0.

Vandiver, H. S. A new type of criteria for the first case of Fermat's last theorem. Read Sept. 7, 1923. Annals of Mathematics, (2), vol. 26, Nos. 1-2, pp. 88-94; Sept.-Dez., 1924.

On sets of three consecutive integers which are quadratic or cubic residues of primes. Read Dec. 29, 1923. This Bulletin, vol. 31, Nos. 1-2, pp. 33-38; Jan.-Feb., 1925.

A property of cyclotomic integers and its relation to Fermat's last theorem. (Second paper.) Read April 24, 1915, and April 27, 1918. Annals of Mathematics, (2), vol. 26, No. 3, pp. 217-232; March, 1925.

On the power characters of units in a cyclotomic field. Read Dec. 28, 1916. American Journal of Mathematics, vol. 47, No. 2, pp. 140-147; April, 1925.

Laws of reciprocity and the first case of Fermat's last theorem. Read Sept. 11, 1925. Proceedings of the National Academy of Sciences, vol. 11, No. 6, pp. 292-298; June, 1925.

- On the distribution of quadratic and higher residues. Read 0ct. 28, 1916. This Bulletin, vol. 31, No. 7, pp. 346-350; July, 1925.

Veblen, 0. Remarks on the foundations of geometry. Read Dec. 31, 1924. This Bulletin, vol.31, Nos.3-4, pp.121-141; March-April, 1925.

Veblen, 0., and Thomas, J. M. Projective normal coordinates for the geometry of paths. Read May 2,1925. Proceedings of the National Academy of Sciences, vol. 11, No. 4, pp. 204-207; April, 1925.

WAHLIN, G. E. On the solution of diophantine equations by means of ideals. Read Dec. 26, 1924. This Bulletin, vol. 31, No. 8, pp. 430-444; Oct., 1925.

WALSH, J. L. Some two-dimensional loci. Read Oct. 25, 1924. Quarterly Journal of Pure and Applied Mathematics, vol.50, No. 2, pp. 154-165; Aug., 1924.

On Pellet's theorem concerning the roots of a polynomial. Read Dec. 27, 1923. Annals of Mathematics, (2), vol. 26, Nos. 1-2, pp. 59-64; Sept.-Dec., 1924.

Wedderburn, J. H. M. A theorem on simple algebras. Read May 3, 1924. This Bulletin, vol. 31, Nos. 1-2, pp. 11-13; Jan.-Feb., 1925.

The absolute value of the product of two matrices. Read May 2, 1925. This Bulletin, vol. 31, No. 7, pp. 304-308; July, 1925.

WeIsNer, L. Groups in which the normaliser of every element except identity is abelian. Read Sept. 8, 1925. This Bulletin, vol. 31, No. 8, pp. 413-416; Oct., 1925.

On the number of elements in a group which have a power in a given conjugate set. Read Feb. 28, 1925. This Bulletin, vol. 31, Nos. 9-10, pp. 492-496; Nov.-Dec., 1925. 
Wiener, N. The Dirichlet problem. Read May 3, 1924. Journal of Mathematics and Physics of the Massachusetts Institute of Technology, vol. 3, No. 3, pp. 127-147; April, 1924.

Note on a paper of 0. Perron. Read Dec. 30, 1924. Journal of Mathematics and Physics of the Massachusetts Institute of Technology, vol. 4, No. 1, pp. 21-32; Jan., 1925.

- A contribution to the theory of interpolation. Read Dec. 28, 1923. Annals of Mathematics, (2), vol. 26, No. 3, pp. 212-216; March, 1925.

The solution of a difference equation by trigonometrical integrals. Read Feb. 28, 1925. Journal of Mathematics and Physics of the Massachusetts Institute of Technology, vol. 4, No. 3, pp. 153-163; May, 1925.

Note on quasi-analytic functions. Read Dec. 30, 1924. Journal of Mathematics and Physics of the Massachusetts Institute of Technology, vol. 4, No. 4, pp. 193-199; July, 1925.

Wilder, R. L. A theorem on continua. Read May 3, 1924. Fundamenta Mathematicae, vol. 7, pp. 311-313; 1925.

- Concerning continuous curves. Read April 15, 1922, Dec. 29, 1922, and Febr. 24, 1923. Fundamenta Mathematicae, vol. 7, pp. 340-377; 1925.

Wilson, W. A. On the Oscillation of a continuum at a point. Read Sept. 10, 1925. Transactions of this Society, vol. 27, No. 4, pp. 429-440; Oct., 1925.

WILson, W. H. Two general functional equations. Read (Southwestern Section) Nov. 29, 1924. This Bulletin, vol. 31, No. 7, pp. 330-334; July, 1925.

Winger, R. M. On the invariants of the ternary icosahedral group. Read (San Francisco Section) Dec.22, 1923. Mathematische Annalen, vol. 93, Nos. 3-4, pp. 210-216; Jan., 1925.

ZeLDIN, S. D. A classification of integral invariants in the calculus of variations. Read Dec. 27, 1923. Tôhoku Mathematical Journal, vol. 24, Nos. 1-2, pp. 121-124; Dec., 1924. 